Historia: Jurnal Program Studi Pendidikan Sejarah

Vol. 3 No. 1 (2018): 48-59

P-ISSN 2301-8305

E- ISSN 2599-0063

\title{
PERKEMBANGAN KEHIDUPAN SOSIAL BUDAYA MASYARAKAT MANTANG KAMPUNG BUBU DESA SAWANG TANJUNG BATU KUNDUR
}

\section{THE DEVELOPMENT OF SOCIO-CULTURAL LIFE OF MANTANG VILLAGE KAMPUNG BUBU VILLAGE SAWANG TANJUNG BATU KUNDUR}

\author{
Afrinel Okwita ${ }^{1}$, Nopitasari ${ }^{2}$ \\ ${ }^{I}$ Prodi Pendidikan Sejarah, FKIP, UNRIKA ${ }^{2}$ Prodi Pendidikan Sejarah, FKIP, UNRIKA \\ ${ }^{1}$ aaftuteh@gmail.com, ${ }^{2}$ nopitasari@gmail.com
}

\begin{abstract}
Abstrak
Tujuan penelitian ini untuk mendeskripsikan perkembangan kehidupan sosial budaya masyarakat mantang Kampung Bubu Desa Sawang Tanjung Batu Kundur. Penelitian ini dilaksanakan di Kampung Bubu, sumber data dalam penelitian ada dua yaitu sumber primer dan sumber skunder. Teknik pengumpulan data dilakukan melalui observasi, wawancara dan dokumentasi. Setelah data terkumpul dianalisis dengan model interaktif yaitu reduksi data penyajian data dan penarikan kesimpulan. Hasil penelitian menunjukan bahwa Kampung Bubu adalah pemukiman Masyarakat Mantang atau orang asli. Pada awalnya kehidupan masyarakat Mantang Kampung Bubu masih sangat tradisional, dilihat dari kehidupan pemukiman di Kampung Bubu pada tahun 1996, rumah-rumah penduduk yang dulunya masih terdapat bahan-bahan seperti papan sebagai dinding dan daun sagu sebagai atap namun dengan adanya perkembangan zaman kehidupan sosial budaya masyarakat setempat mulai berkembang baik dari segi pendidikan, matapencaharian, sosial, budaya dan agama pun mulai berkembang pesat. perkembangan yang terlihat dari penelitian ini adalah dari sosial yang awalnya masyarakat Mantang tidak dapat bersosialisasi dengan masyarakat luar, sedangkan dari segi budaya masyarakat Mantang dari pernikahan yang awalnya menggunakan tradisi pukul anjing, namun dengan adanya perkembangan tradisi tersebut dihilangkan. Selain budaya pernikahan masyarakat mantang yang dahulunya tidak mengenal agama sekarang sudah menganut agama sesuai dengan kepercayaan masing-masing.
\end{abstract}

Kata Kunci: kehidupan sosial, budaya, mantang

\section{Abstract}

The purpose of this study was to describe the development of the socio-cultural life of the mantang community in Kampung Bubu, Sawang Tanjung Batu Kundur Village. This research was conducted in Bubu Village, the data sources in the study were two, namely primary sources and secondary sources. Data collection techniques are carried out through observation, interviews and documentation. After the data collected is analyzed by interactive models, namely data reduction data presentation and conclusion drawing. The results of the study show that Bubu Village is a settlement of the Mantang Community or native people. In the beginning, the life of the Mantang community in Kampung Bubu was still very traditional, judging from the settlement life in Kampung Bubu in 1996, the houses that used to be used as boards and sago walls as a roof but with the development of the times of socio-cultural life local communities began to develop both in terms of education, livelihood, social, cultural and religious began to develop rapidly. The development seen from this research is that from the social aspect, the Mantang people were initially unable to socialize with the outside community, while in terms of the culture of the Mantang community from marriage which initially used the tradition of dog hitting, the development of the 
Historia: Jurnal Program Studi Pendidikan Sejarah

Vol. 3 No. 1 (2018): 48-59

P-ISSN 2301-8305

E- ISSN 2599-0063

tradition was eliminated. In addition to the culture of abusive community marriage which previously did not know religion, it has now embraced religion in accordance with their respective beliefs.

Keywords: Social life, Culture, Mantang

\section{PENDAHULUAN}

Kepulauan Riau merupakan salah satu Provinsi yang terbentuk dalam suasana otonomi daerah. Pembentukan Provinsi Kepulauan Riau merupakan kehendak dari masyarakat yang menginginkan terselenggaranya pemerintahan yang efektif dan efesien. Perjuangan yang melelahkan dari para tokoh-tokoh yang memprakarsai pembentukan Provinsi Kepulauan Riau akhirnya membuahkan hasil dengan disahkannya Undangundang Nomor 25 Tahun 2002 tentang pembentukan Provinsi Kepulauan Riau pada tanggal 24 September 2002. Provinsi Kepulauan Riau merupakan provinsi ke-32 dengan wilayah meliputi Kabupaten Bintan, Kabupaten Karimun, Kabupaten Lingga, Kabupaten Natuna, Kota Batam, dan Kota Tanjung Pinang. Provinsi Kepulauan Riau merupakan salah satu pemekaran dari Riau pada tahun 2002, seperti yang kita ketahui bahwa masyarakat kepulauan ini identik dengan matapencaharian nelayan (Gunawan, 2007:16).

Sebagai daerah Kepulauan, Kepulauan Riau memiliki banyak pulau, salah satunya Pulau Tanjung Batu Kundur yang terletak pada Kabupaten Karimun. Pada daerah Tanjung Batu Kundur Kabupaten Karimun terdapat desa kecil yaitu Desa Sawang Kundur Barat. Berdasarkan kehidupan masyarakat pulau Tanjung Batu, dapat disimpulkan bahwa penduduk pulau ini bermata pencaharian sebagai nelayan. Berbeda dengan masyarakat Desa Sawang Kundur Barat, mata pecaharian masyarakat Tanjung Batu Kundur diantaranya pada sektor industri timah meskipun profesi petani menjadi profesi utama.

Terbentuknya Kecamatan Kundur Barat merupakan suatu upaya untuk mendekatkan pelayanan terhadap masyarakat. Kehadirannya sebagai institusi ekskutif yang akan menjalankan roda pemerintahan dan pembangunan kemasyarakatan diharapkan dapat menjawab setiap permasalahan maupun tantangan yang muncul sesuai dengan perkembangan sosial ekonomi, sosial budaya, dan lainnya dalam masyarakat. 
Historia: Jurnal Program Studi Pendidikan Sejarah

Vol. 3 No. 1 (2018): 48-59

P-ISSN 2301-8305

E- ISSN 2599-0063

Sebagai daerah yang masyarakatnya menyeluruh, kehidupan agama yang beraneka ragam dimana ada yang beragama Islam, Kristen, dan Budha.

Penulis akan melakukan penelitian di desa Sawang Kundur Barat lebih tepatnya di Kampung Bubu. Bubu adalah nama tempat yang diberi oleh penghuni pedalaman Sawang, masyarakat Bubu ini bersuku Mantang (orang asli). Tempat tinggal mereka berada di tepi pantai, oleh karena itu dalam segi ekonomi masyarakat Mantang ini bermata pencaharian nelayan dan berburu. Kehidupan masyarakat Mantang pada tahun 1996 masih sangat tradisional belum dapat menerima masyarakat luar untuk dapat berbaur dengan mereka dalam bentuk kehidupan sosial maupun budayanya, dari segi kepercayaan masyarakat Mantang pada saat itu belum mengenal agama bahkan mereka tidak mengetahui apa agama mereka. Masyarakat Mantang ini juga masih menjaga dan mempertahankan kebudayaan dari suku mereka, diantaranya dari segi adat, mata pencaharian, maupun kepercayaannya. Budaya yang dilakukan Suku Mantang ini terdapat adat yang unik yaitu ketika melakukan prosesi pernikahan, janji pernikahan itu menggunakan seekor binatang. Sebagian masyarakat Mantang pendidikan dalam kehidupan mereka itu sangat minim mereka beranggapan kalau pendidikan itu tidak penting untuk kehidupan mereka karena mereka lebih mementingkan pekerjaan mereka yang dapat menghasilkan uang dari pada harus menuntut ilmu.

Perkembangan masyarakat Mantang ini sedikit demi sedikit mengalami perkembangan dengan mulai menerima kedatangan dari seorang pendeta, disinilah terdapat peran penting pendeta yang sangat berpengaruh terhadap perkembangan kehidupan masyarakat Mantang. Hal ini dibuktikan dari banyaknya perkembanganperkembangan sosial, budaya, ekonomi, maupun agama yang terjadi pada masyarakat Mantang tersebut. Kehidupan sosial mereka yang dulunya masih kurang dalam segi bersosialisasi dengan adanya perkembangan pengetahuan, mereka sedikit dapat membaur untuk mengelola hasil barter tangkapan nelayan dan buruannya. Kondisi pendidikan masyarakat Mantang juga mengalami perkembangan dimana yang dulunya mereka tidak mementingkan pendidikan, pada tahun 2002 masyarakat Mantang mulai mempunyai keinginan untuk bersekolah walaupun jenjang sekolah yang mereka capai hanya sampai jenjang SD (Sekolah Dasar). 
Historia: Jurnal Program Studi Pendidikan Sejarah

Vol. 3 No. 1 (2018): 48-59

P-ISSN 2301-8305

E- ISSN 2599-0063

Melihat dari semua latar belakang yang telah dijelaskan di atas, serta untuk mengetahui sejauh mana perkembangan sosial budaya masyarakat Mantang, maka dari pada itu penulis melakukan penelitian dengan judul "Perkembangan Kehidupan Sosial Budaya Masyarakat Mantang Kampung Bubu Tanjung Batu Kundur.

\section{Teori Perkembangan}

Menurut teori Parson, masyarakat akan dapat berkembang dengan melalui tiga tingkatan utama yaitu dalam teori fungsional imperatives diantaranya: primitif, intermediate, dan modern (Narwoko, 2007: 371).

\section{a. Primitif}

Tingkatan primitif dapat dilihat sebagai masyarakat keluarga. Ada difusi fungsional dalam hubungan sosial, artinya, tidak dikenal perbedaan prilaku dalam peranan yang berbeda-beda sebagai mana yang terjadi pada masyarakat modern. Konsekuensinya, keberadaan norma sosial bersifat given, dan sudah terformat sedemikian rupa dari generasi sebelumnya. Dalam kondisi demikian, maka status sosial bersifat ascribed yang pada gilirannya menentukan dalam berbagai aktifitas individu warganya, termasuk dalam aktifitas produksi, secara keagamaan dan seterusnya. Pola masyarakat seperti ini dengan demikian tak dimungkinkan adanya aktifitas alternative.

Itulah sebabnya mengapa tipe masyarakat primitif parson bisa juga digolongkan sebagai tipe masyarakat mekanis seperti dikatakan Durkheim. Pada masyarakat tingkat primitif, kesaadaran kolektif begitu mengedepan sehingga pertimbangan integrasi dari keseluruhan fungsi-fungsi unsurnya sangatlah penting. Karena itu, wajar apabila pelaksanaan dan pengendalian ketiga subsistem lainnya seperti upacara keagamaan, pelaksanaan kekuasaan politik, pelaksanaan hukum, dan penentuan kebutuhan material berada di tangan keluarga/keturunan. Jadi, peranan organisasi keluarga begitu dominan dan sekaligus sebagai tanda evolusi awal dalam setiap perkembangan masyarakat (Narwoko, 2007: 371).

Pada masyarakat primitif identitas sosial umumnya didasarkan pada pandangan terhadap simbol-simbol religius, atau dunia dongeng yang penuh idealisme dan karna itu 
Historia: Jurnal Program Studi Pendidikan Sejarah

Vol. 3 No. 1 (2018): 48-59

P-ISSN 2301-8305

E- ISSN 2599-0063

perlu dan patut dicontoh dan dijadikan rujukan dalam berprilaku bermasyarakat. Dunia idealisme religius ini sudah ada sejak nenek moyang dan generasi baru tinggal menerima, menjalankan, dan meneruskan pada generasi berikutnya. Dalam mitos keagamaan telah lengkap digambarkan tentang bentuk-bentuk prilaku yang baik dan seharusnya diikuti semua warga, dan bentuk-bentuk tingkah laku yang tidak baik dan karenanya harus ditinggalkan. Para warga tidak diberikan kesempatan untuk bertingkah laku lain, apalagi sampai berani melawannya, kecuali tinggal mengikutinya.

\section{b. Intermediate}

Struktur normatif keanggotaan struktur komunitas secara tidak terelakan menjadi berubah. Seiring dengan itu, penemuan bahasa yang sangat istimewa karena bisa digunakan sebagai kriteria dalam memisahkan antara dunia primitif dan dunia beradab (yang mulai pada tingkat intermediate). Dengan bahasa tulisan dimungkinkan adanya diferensiasi struktural antara bidang kultural dan bidang lainnya dalam masyarakat. Selain itu, bahasa tulisan memungkinkan akumulasi, pemeliharaan dan berlanjutnya tradisi kultural. Bahasa tulisan juga bisa sebagai stabilisator, karena eksistensinya tidak lagi banyak bergantung kepada para penghafal.

Komunikasi bisa terjadi secara tidak langsung, sehingga tingkat koordinasi antara warga bisa lebih efektif tanpa harus berlangsung secara face to face. Kemampuan berbahas tulis dalam banyak hal juga berpengaruh terhadap status sosial orang tertentu sekaligus bisa didayagunakan untuk mempertahankan status qou-nya. Tapi, saat kemampuan baca tulis kian merata di hampir semua orang anggota komunitas, maka dengan baca tulis bisa menjadi sarana berkembangnya demokrasi.

\section{c. Modern}

Hukum formal memadai munculnya masyarakat modern, yakni munculnya institusi pengadilan yang bebas. Diferensiasi struktural bidang pemerintahan. Dalam sejarah evaluasi sosial, fungsi politik yang mencakup penggunaan paksaan umumnya dipandang sebagai fungsi sosial yang terpisah dari jaringan organisasi kekeluargaan primitif. Penggunaan kekuasaan ini bisa jadi dilatarbelakangi oleh, misalnya, tekanan 
Historia: Jurnal Program Studi Pendidikan Sejarah

Vol. 3 No. 1 (2018): 48-59

P-ISSN 2301-8305

E- ISSN 2599-0063

penduduk dan penemuan teknologi pertanian. Kedua temuan itu dalam banyak kasus menyebabkan pola hidup menetap. Pola hidup menetap menuntut perlunya pembagian tanah secara internal yang barangkali secara ekonomi akan membawa keuntungan ekonomis yang saling berbeda.dari sinilah mulai muncul stratifikasi dan diferensiasi vertikal. Dampaknya bisa diduga, kalau status sosial sebelumnya berdasarkan pada faktor keturunan (ascribad status), berubah menjadi kepemilikan tanah (ekonomi)

Fungsi pencapaian tujuan. Fungsi berhubungan antara komunitas dan individu anggota komunitas. Aspek ini mengkristal dalam bentuk sosialisasi, sebab setiap warga komunitas komunitas memerlukan tingkat pengembangan dan motivasi untuk berpartisipasi dalam kehidupan sosial. Karena sosialisasi saja ternyata kurang memadai, maka perlu dilengkapi dengan kontrol sosial, khususnya dalam kerangka memaksa individu.dalam konteks ini, aspek politik kehidupan masyarakat sangat jelas. Sebab, masyarakat memerlukan pengorganisasian tindakan konteks dalam rangka mencapai tujuan bersama, termasuk atau dengan para subkolektifnya: politik kehidupan sosial. (Narwoko, 2007: 374).

\section{METODOLOGI}

Metode dalam penelitian ini adalah menggunakan metode penelitian kualitatif deskriptif, di dalam metode ini terdapat beberapa bagian yaitu:

\section{Sumber data}

Menurut Bungin (dalam Ibrahim, 2015: 68) menyatakan bahwa data primer adalah segala informasi, fakta, dan realitas yang terkait atau relevan dengan penelitian. Disebut sebagai data utama (primer), karena data tersebut menjadi penentu utama berhasil atau tidaknya suatu penelitian. Artinya, hanya dengan didapatkannya data tersebut sebuah penelitian dapat dikatakan berhasil dikerjakan. Data primer didefinisikan sebagai data yang diambil dari sumber primer atau sumber pertama dilapangan.

Data sekunder adalah segala informasi, fakta, dan realitas yang juga terkait atau relevan dengan penelitian, namun tidak secara langsung atau tidak begitu jelas relevansi. Menurut Bungin dalam Ibrahim, 2015: 69) menyebutkan bahwa sebagai data yang 
Historia: Jurnal Program Studi Pendidikan Sejarah

Vol. 3 No. 1 (2018): 48-59

P-ISSN 2301-8305

E- ISSN 2599-0063

diperoleh dari sumber kedua (data sekunder). Data sekunder ini menurutnya terbagi kedalam dua bentuk; pertama, internal data yang tersedia tertulis pada sumber data sekunder, kedua eksternal data yang diperoleh dari sumber luar seperti sensus atau data statistik.

\section{Teknik pengumpulan data}

\section{a. Observasi (pengamatan)}

Observasi adalah aktivitas pencatatan fenomena yang dilakukan secara sistematis. Pengamatan dapat dilakukan secara terlibat (partisipatif) ataupun nonpartisipatif. Maksudnya, pengamatan terlibat merupakan jenis pengamatan yang melibatkan peneliti dalam kegiatan orang yang menjadi sasaran penelitian, tanpa mengakibatkan perubahan pada kegiatan atau aktivitas yang bersangkutan dan tentu saja dalam hal ini peneliti tidak menutupi dirinya selaku peneliti. Untuk menyempurnakan aktivitas pengamatan partisipatif ini, peneliti harus mengikuti kegiatan keseharian yang dilakukan informan dalam waktu tertentu, memerhatikan apa yang terjadi, mendengarkan apa yang dikatakannya, mempertanyakan informasi yang menarik, dan mempeljari dokumen yang dimiliki (Idrus, 2009: 101).

\section{b. Wawancara}

Menurut Koentjaraningrat (dalam Idrus, 2009, 108) wawancara merupakan alat rechecking atau pembuktian terhadap informasi atau keterangan yang diperoleh sebelumnya. Model wawancara yang dilakukan meliputi wawancara tak berencana yang berfokus dan wawancara sambil lalu. Wawancara tak berencana berfokus adalah pertanyaan yang diajukan secara tidak terstruktur, namun selalu berpusat pada satu pokok masalah tertentu. Wawancara sambil lalu adalah wawancara yang tertuju kepada orangorang yang terpilih tanpa melalui seleksi terlebih dahulu secara diteliti, tetapi dijumpai secara kebetulan.

Teknik wawancara dibagi menjadi dua jenis yaitu wawancara terstruktur dan wawancara tidak terstruktur. Teknik wawancara yang dilakukan dalam pengumpulan data penelitian ini adalah wawancara tidak terstruktur, dimana dalam wawancara inilah yang lebih sesuai dalam penelitian kualitatif sebab jenis wawancara tidak terstruktur ini memberi peluang kepada peneliti untuk mengembangkan pertanyaan-pertanyaan 
Historia: Jurnal Program Studi Pendidikan Sejarah

Vol. 3 No. 1 (2018): 48-59

P-ISSN 2301-8305

E- ISSN 2599-0063

penelitian. Meski disebut wawancara tidak terstruktur,bukan berarti dialog-dialog yang ada lepas begitu saja dari konteks. sejak awal peneliti harus memiliki fokus pembicaraan yang diarahkan kepada fokus penelitian (Idrus, 2009:107).

\section{c. Dokumentasi}

Dokumen atau dokumentasi dalam penelitian mempunyai dua makna yang sering di pahami secara keliru oleh peneliti pemula. Pertama, dokumen yang dimaksudkan sebagai alat bukti tentang sesuatu, termasuk catatan-catatan, foto, rekaman video atau apapun yang dihasilkan oleh seorang peneliti. Dokumen bentuk ini lebih cocok disebut sebagai dokumentasi kegiatan/kenang-kenangan. Kedua, dokumen yang berkenaan dengan pristiwa atau momen kegiatan yang telah lalu, yang padanya mungkin dihasilkan sebuah informasi, fakta dan data yang diinginkan penelitian (Ibrahim, 2015: 93).

\section{d. Teknik Analisis Data}

Dalam membahas tentang analisis data dalam penelitian kualitatif, para ahli memiliki pendapat yang berbeda. Huberman dan Miles (dalam Idrus, 2009: 147-151) mengajukan model analisis data yang disebut sebagai model interaktif. Model interaktif ini terdiri dari tiga yaitu

1. Pengumpulan data

Proses pengumpulan data yang pertama kali penulis lakukan adalah dengan melakukan observasi atau pengamatan disekitar tempat yang akan dijadikan lokasi penelitian. Observasi ini penulis lakukan agar dapat gambaran secara umum tentang bagaimana keadaan disana, seperti mengamati bagaiman kondisi sosial, kondisi fisik desa tersebut. Setelah mendapatkan gambaran umum mengenai lokasi penelitian kemudian penulis melakukan wawancara dengan masyarakat setempat untuk mendukung data yang telah diperoleh melalui observasi sebelumnya.

2. Reduksi data

Reduksi data merupakan proses pemilihan, pengabstrakan, dantransformasi data kasar yang muncul dari catatan-catataan tertulis dilapangan. Reduksi data dalam penelitian ini dilakukan dengan melakukan seleksi, membuat ringkasan, menggolongkan untuk lebih tajam, mempertegas, menyingkat, membuang bagian yang tidak diperlukan, 
Historia: Jurnal Program Studi Pendidikan Sejarah

Vol. 3 No. 1 (2018): 48-59

P-ISSN 2301-8305

E- ISSN 2599-0063

dan mengatur data agar dapat ditarik kesimpulan akhir secara tepat dan dilanjutkan dengan proses verifikasi.

Dalam proses ini penulis melakukan pemiliha data yang telah diperoleh selama observasi serta hasil wawancara yang telah dilakukan. Pemilihan data ini dilakukan untuk memudahkan penulis untuk mengolah data agar tetap sesuai dengan rumusan masalah yang ada. Pada pemilihan data ini juga dilakukan pengkodean agar memudahkan penulis untuk mengelompokkan data berdasarkan kode-kode yang sudah ada.

3. Penyajian Data

Penyajian data dibatasi sebagai sekumpulan informasi yang tersusun dan memberikan kemungkinan adanya penarikan kesimpulan dan pengambilan tindakan. Penyajian data cendrung mengarah pada penyederhanaan data, kompleks kedalam kesatruan bentuk yang sederhana dan selektif sehingga mudah dipahami.

Setelah pemilihan data dilakukan kemudian barulah data disajikan dengan mendeskripsikan mengenai hasil wawancara derta observasi yang telah dilakukan penulis. Dalam penyajian data ini, penulis melakukan analisis terhadap apa yang telah didapatnya selama dilapangan.

4. Penarikan Kesimpulan

Penarikan kesimpulan sebagai langkah akhir dalam perbuatan suatu laporan sebagai usaha untuk mencari atau memahami makna, keteraturan pola-pola penjelasan, alur sebab akibat. Kesimpulan yang ditarik segera diverifikasi dengan melihat dan mempertanyakan kembali sambil melihat catatan lapangan agar memperoleh lapangan yang lebih cepat.

Analisa yang telah dilakukan dalam penyajian data, akan mempermudah penulis untuk mengambil kesimpulan. Dalam perbuatan kesimpulan ini penulis meringkas hasil dari wawancara serta observasi yang telah dianalisis dalam penyajian data. Kesimpulan ini diambil untuk lebih memudahkan penulis dalam mengkrucutkan atau mempersempit hasil analisis tersebut yang hanya sesuai rumusan masalah yang telah ada.

\section{PEMBAHASAN}


Historia: Jurnal Program Studi Pendidikan Sejarah

Vol. 3 No. 1 (2018): 48-59

P-ISSN 2301-8305

E- ISSN 2599-0063

Kampung Bubu menurut silsilah telah terbagi menjadi tiga bagian yaitu Kampung Bugis, Bubu darat, dan Bubu laut. Penamaan ketiga tersebut sesuai dengan kebiasaan umum pemberian nama kampung tradisional yaitu berdasarkan kondisi alam yang terdapat di tempat tersebut. masyarakat yang tinggal di Kampung Bubu tersebut hampir setiap KK bermayoritas suku Bugis, hal ini yang menyebabkan penamaan Kampung Bubu Bugis itu di kenal oleh kalangan masyarakat sekitar. Penamaan Kampung Bubu Darat pula dikarenakan Pulau berdasarkan daratan yang berada agak jauh dari permukaan laut, yang terletak bagian tengah Kampung Bugis dan Bubu laut. Sedangkan penamaan Kampung Bubu laut itu di ambil dari keberadaan kampung tersebut yang bersebelahan dengan permukaan pantai. Suku yang terdapat di kampung Bubu tidak hanya masyarakat Mantang atau suku asli saja tetapi ada juga yang bersuku Bugis, selain itu hal menarik dari perkampungan di Bubu ini karena adanya perbedaan bahasa antara ke dua kampung tersebut.

\section{Kehidupan Sosial Masyarakat}

Pada tahun 1996-2016 menjadi titik perubahan di Kampung Bubu. Banyak perkembangan yang terjadi di Kampung Bubu. Salah satunya adalah tentang bagaimana pemukiman penduduk itu sendiri. Kampung Bubu memiliki dua tipe lokasi rumah yaitu yang berada di pesisir pantai dan daratan. Perbedaan lokasi rumah antara bibir pantai dan daratan tersebut berpengaruh terhadap bentuk dan fungsi rumah. Hal ini karena bentuk rumah disesuaikan pemiliknya untuk keperluan sehari-hari baik bekerja maupun untuk kehidupan sosial. kondisi kehidupan sosial Masyarakat Mantang juga sangat lemah, dilihat dari cara sosialisasi masyarakat tersebut dengan penduduk setempat yang masih pilih-pilih, hubungan antara penduduk Bubu Bugis dengan Bubu laut tidak terlalu harmonis, dikarenakan kurangnya pendidikan dan pemikiran diantara mereka yang menyebabkan mereka pilih-pilih dalam bersosialisasi.

\section{Kehidupan Budaya Masyarakat}

Setiap kehidupan bermasyarakat budaya sudah sangat lumrah, perkembangan budaya pada Kampung Bubu adalah perubahan bagaimana cara orang Mantang berprilaku. Perubahan ini mencakup pada resepsi pernikan mereka pada tahun 1996 yang menggunakan seekor anjing untuk untuk mengesahkan pernikahan mereka. pada tahun 
Historia: Jurnal Program Studi Pendidikan Sejarah

Vol. 3 No. 1 (2018): 48-59

P-ISSN 2301-8305

E- ISSN 2599-0063

2004an karena pola pikir mereka sedikit banyaknya mulai berkembang, masyarakat berpikir bahwa hal tersebut tidak berpengaruh bagi kelancaran acara pernikahan tersebut, untuk itu tradisi yang dilakukan oleh nenek moyang orang Mantang tersebut di hapuskan atau dihilangkan dengan persetujuan masyarakat setempat.

Selain dari segi adat pernikahan yang kebudayaan yang dapat dilihat dari kehidupan masyarakat Mantang Kampung Bubu ini adalah dari segi kepercayaannya, dimana pada tahun 1996 masyarakat Mantang Kampung Bubu tidak mempunyai agama, mereka tidak mengetahui kepercayaan mana yang harus mereka anut, disebabkan karena kurangnya pengetahuan masyarakat lokal yang membuat mereka tidak memperdulikan hal tersebut. Mereka hanya memfokuskan pekerjaan mereka untuk dapat mencukupi kehidupan seharihari.

Hal ini berlangsung hingga tahun 2000an. Pada tahun 2004 dengan masuknya seorang pendeta ke pemukiman Kampung Bubu memberi perubahan yang bertahap terhadap masyarakat lokal, salah satunya dari segi agama atau kepercayaan ini sedikit demi sedikit sudah mulai tampak perkembangannya. Melalui ilmu-ilmu yang diberikan oleh pendeta masyarakat lokal mulai mengembangkan pengetahuan yang diberikan oleh pendeta dengan menjalankan kewajiban mereka untuk beribadah ke gereja sesuai dengan agama mereka yaitu Kristen.

\section{KESIMPULAN DAN SARAN}

Perkembangan dari kehidupan sosial terlihat dari pola hubungan interaksi masyarakat dimana mereka yang dulunya kurang menerima pengaruh dari luar sekarang sudah bisa bersosialisasi dengan masyarakat lain. Hal ini disebabkan oleh adanya seorang pendeta yang mampu mengubah pola pikir masyarakat. dari segi pendidikan mereka sudah berkembang dahulu mereka tidak mengenal pendidikan sekarang sudah melanjut sampai SMA.

Perkembangan dalam kehidupan budaya terlihat dari segi kepercayaan mereka yang dahulunya tidak memiliki kepercayaan sekarang sudah memiliki agama, mayoritasnya mereka beragama kristen. Dari segi adat istiadat seperti pernikahan dahulu 
Historia: Jurnal Program Studi Pendidikan Sejarah

Vol. 3 No. 1 (2018): 48-59

P-ISSN 2301-8305

E- ISSN 2599-0063

mereka menggunakan adat pukul anjing, sekarang sudah melakukan adat pernikahan seperti masyarakat pada umumnya.

Berdasarkan kesimpulan diatas, penulis mencoba untuk menuangkan beberapa saran yang diharapkan berguna bagi Masyarakat Mantang Kampung Bubu:

1. Diperlukan kerjasama antara pemerintah untuk meningkatkan pola pikir masyarakat dalam mengembangkan kehidupan masyarakat Mantang dari segi sosialisasi maupun dari pendidikannya.

2. Pengadaan tenaga pengajar yang menunjang di rasa mampu untuk mempermudah meningkatkan pola pikir masyarakat.

3. Bagi mahasiswa khususnya pendidikan sejarah lebih dapat mengangkat sejarah lokal masyarakat asli Kepulauan Riau khususnya yang ada di Pulau Tanjung Batu.

4. Bagi pembaca agar lebih tertarik untuk mengetahui kehidupan oarng Mantang di Kepulauan Riau khususnya di Pulau Tanjung Batu. Agar masyarakat luar lebih mengetahui suku asli Tanjung Batu dan tidak berfikiran negatif tentang kehidupan masyarakat Mantang.

\section{REFERENSI}

Gunawan, Markus. (2008). Provinsi Kepulauan Riau, Batam: Titik Cahaya Elka. Ibrahim, (2015), penelitian kualitatif, Bandung: ALFABETA

Idrus, Muhammad. (2006). Metode penelitian ilmu sosial, Jakarta: Erlangga.

Narwoko Dwi-Bagong suyanto(ed) (2007). Sosiologi Teks Pengantar dan Terapan, Jakarta: Kencana. 